\title{
BUSINESS AND REGIONAL MODELS FOR THE APPLICATION OF THE CIRCULAR ECONOMY
}

\author{
T. Turlakova* \\ Department of “Agricultural Economics”, University of economics - Varna, Bulgaria
}

\begin{abstract}
Since the beginning of the Industrial Revolution, the linear model of economic development has been applied worldwide. Today, this model is heavily criticized for a variety of reasons: from rising commodity prices due to their depletion to more significant economic problems such as the need to protect the environment and the increasing energy demand. After a number of scientific discussions and studies, the concept of the "circular economy" underlying the regenerative approach of production is needed. Circular economy is realized through a variety of measures, activities and approaches, depending on the characteristics of the region and / or the sector, as a result of which regional and business models are typified.

The purpose of this report is to analyze the existing and potential regional and business models of the circular economy in the context of sustainable development. Different empirical approaches have been used to find innovative solutions for assessing the models of the circular economy in Bulgaria, including agriculture. The resulting summaries are the basis for proposing new ecological initiatives and measures.
\end{abstract}

Key words: agro-ecological approach, circular business models, sustainable development

\section{INTRODUCTION}

Since the beginning of the Industrial Revolution, the linear model of economic development has been applied worldwide. Today, this model is heavily criticized for a variety of reasons: from rising commodity prices due to their depletion to more significant economic problems such as the need to protect the environment and the increasing energy demand. After a number of scientific discussions and studies, the concept of the "circular economy" is formed as a base of the regenerative approach of production.

The purpose of this article is to analyze the existing and potential regional and business models of the circular economy in the context of sustainable development.

\section{The concept of the circular economy and the social benefits}

The circular economy is an economy in which the waste from production processes and

\footnotetext{
*Correspondence to: Teodorina Turlakova' Department of "Agricultural economics", University of economics - Varna, Bulgaria, 9002 Varna, 77 Knyaz Boris I Blvd, +359888 736 996, tturlakova@ue-varna.bg
}

consumption is used circularly, put back into the same or another production. A similar approach to raw materials helps the flow of goods and services. According to EPRS (5), when a product reaches the end of its life cycle, raw materials remain inside the system, so that this product can be used repeatedly for production purposes and create additional value.

The approaches of circular material flow as an economic model (in the conditions of limited raw materials) serve as a prerequisite for applying the concepts of industrial ecology, industrial symbiosis and the green economy. A number of authors consider the circular economy as a key part of the green economy as it deals with the management and prevention of waste production and raw material efficiency, while the green economy is a broader concept, which also includes the social aspect of the impact on the society and the sustainability of ecosystems (4).

The concept of a circular economy was first introduced in 1989 by two British economists David Pierce and Professor Kerry Turner. In the book "Economics of the Environment and 
TURLAKOVA T.

Natural Resources" (9), they point out that the traditional economy that has been created is "open ended" without any tendency for re-use. The concept of traditional economy is backed by the view that nature is treated as an exhaustible resource.

The figurative representation of the circular economy illustrates the commonly accepted idea of the concept whereby the recycling model creates production and consumption systems where everything that has been considered as waste until now is invested in other uses. According to a study in 2015 by Lacey et al. (7) the forecasted profit from the introduction of circular economy principles into the business models will reach on a global scale \$ 4.5 trillion in 2050

The Circular Economy offers an alternative model whereby the usefulness of products, materials and resources is extended as much as possible and waste is reduced or even eliminated. By "closing the cycle", the circular economy is evolving within the limited worldwide material resources. The transition to such an economy involves a wide range of activities / sectors - mobility and transport, agriculture, land use and waste management, business development and consumer education affecting almost all of the social layers and levels of government. This transition, however, is not something an institution or a company can independently realize. Interconnection and interaction between stakeholders and sectors is required.

There are four areas where the most significant benefits of the transition to a circular economy are outlined - resource use, the environment, economic and social aspects (creation of new jobs, for example).

Circular economy can increase efficiency in the use of primary raw materials in Europe and the world by preserving materials incorporated in high-value products or by returning waste to the economy as high-quality secondary raw materials. This will help reducing European countries' dependence on imports from other countries.

Thus, supply chains in many sectors will not be affected by the volatility of international commodity markets and the uncertainty of supply due to shortages and / or geopolitical factors.
Between $6 \%$ and $12 \%$ of the consumption of all materials, including fossil fuels, are currently avoided as a result of recycling, waste reduction and ecodesign policies. The maximum that can be achieved with the existing technologies is $10-17 \%$, and by using innovative technologies and improving resource efficiency, inputs used in the EU can be reduced by $24 \%$ by 2030 .

The absolute separation of production and social welfare from the use of resources and energy and related environmental impacts is the main goal of the EU's resource efficiency policy.

Indeed, although the current waste policies are already contributing to this, the European Commission considers that the different combinations of more ambitious waste recycling and packaging targets and the reduction of landfills can lead to a reduction in greenhouse gas emissions of about 424-617 million tonnes of carbon dioxide equivalent over the period 2015-2035, in addition to the reductions resulting from the existing targets.

The implementation of measures other than recycling of waste could further reduce greenhouse gas emissions. For example, it has been established that in the food and beverages, metal products, hotel and restaurant sectors, with the introduction of resource efficiency measures, 100-200 million tonnes of carbon dioxide equivalent greenhouse gas emissions can be avoided annually.

Study from 2016 of the European Environment Agency shows the following benefits of a circular economy (6):

-Improved resource security and reduced import dependence (due to reduced demand / consumption of resources);

- Reduced negative impact on the environment, including drastic reduction in greenhouse gas emissions;

-Economical benefits: new niches for growth and innovation, and savings realised through more effective and efficient use of resources;

-Social benefits - from employment improvement - creating new jobs - to changes in consumer behavior, incl. leading to a healthier and safer way of life.

\section{The circular economy on the European agenda}

The most authoritative definition of a circular economy is given by the Ellen Makarr 
Foundation: "(the circular economy is) an industrial economy that is conceptually regenerating and reproducing natural cycles to actively improve and optimize the systems through which it operates. This means that the eco-efficiency concept aims at transforming materials and related flows in such a way that they build a link to support environmental systems and achieve future economic growth.

The aim is not to minimize the material flow in the chain "from the creation to the end of the life cycle" but to build cyclic "metabolism" from the "creation to creation" type, which allows the materials to maintain their raw material status in the time and generates knowledge for their usage (rising cyclicality). This in itself generates a synergic link between ecological and economic systems - a positive re-engagement between ecology and economics "(2)

The potential of the circular economy is recognized by a number of European countries and regions as well as by the European institutions. In December 2015, The European Commission has approved a targeted package of policies and instruments to promote the circular economy, aiming at increased competitiveness, sustainable growth and increased employment for the continent (5).

The package includes new and revised legislation, including through four legislative proposals to amend the following legal frameworks: the Waste Framework Directive, the Landfill Directive, the Packaging and Packaging Waste Directive, the End-of-Life Vehicles Directives on Batteries and Accumulators and waste batteries and accumulators as well as disused electrical and electronic equipment (8).

The Circular Economy is also the focus of the EU's Urban Agenda Partnerships (1). Partnerships will link the circular economy to waste management and resource efficiency by developing action plans to improve national and local regulations, improve financial instruments, raise awareness and information. The implementation of these plans should lead to a significant increase in reuse and recycling of materials and resources.

Models and cycles of the circular economy Circular economy can be implemented through different cycles that predetermine regional and companies business models:
TURLAKOVA T.

- The cascade cycle: By connecting different companies to local platforms, so the waste from one firm becomes raw materials for another company and so becomes the basis for producing other products. For this reason, it is a good idea to work on shorter life cycles to reimburse faster the costs of collection, processing and returns;

- a multiplication cycle through which the product remains in use for a longer time, with more cycles of use, including re-use, repair and maintenance.

On the basis of the cascade cycle, regional models of circular economy arise, as the various regional factors predetermine the development of a different business segment, which through interconnection between firms builds a business network. For example, the symbiosis of agriculture-industry-agriculture is observed in the North-East region of Bulgaria (NER). It is illustrated by the use of sunflower waste to obtain the so-called sunflower pellets, which in turn serve as a raw material for heating greenhouse production.

As a closed business model, a circular economy is an approach designed to keep components and materials at the highest level of applicability and value throughout the production cycle. The circular economy aims to change the meaning of waste as a nonuseable substance, indicating that it is significant. Circular economics from the economic and consumer point of view, opens the way to improving the productivity and efficiency of raw materials by creating a circular development system.

1. Product as a service. An example of such a practice is the so-called "Leasing of agricultural machinery" for which a certain amount is paid each month and the replacement with a new model such as leasing is continued. Thus, against a certain monthly lease fee, the agrarian entrepreneur always has the latest machine model through extengement programs.

2. Follow-up sales - a business model whereby the company can efficiently recover its used products and then re-market them to be able to win from them for the second, why not for the third time. An example of this is recycled machinery / equipment / tools, etc.

3. Product transformation - not all of the products can be fully restored after use. However, in these used products, there are often parts that are valuable or of high value. 
4. Recycling - the new recycling technology 2.0 is developing extremely fast, allowing for the production of high quality products with fantastic resistance. It is used, for example, by Starbucks, which seeks to turn thousands of tons of coffee and food waste into daily products using bacteria to produce succinic acid. The acid has a variety of uses from disinfectants to bioplastics and medicines.

The circular economic model is based on both the supply of "biological resources" and also on various industrial materials, including fossil fuels, metals, quartz, etc. The application of the circular model is preferable to the use of biological resources and above all developing of bio economic. The re-usage and recycling the "bio-waste" leads to the creation of products from a natural source where additional pollution is avoided. The recycling of bio-waste does not compromise food production and preserves the ecosystem.

\section{Measures, tools, and monitoring to promote the business models}

The proposed measures and instruments outline a production chain that includes different steps to achieve a circular economy and to close the circle. In regional models, it is important to move to the following actions: mapping the production chain in the region or individual regions, evaluating the appropriate production chain to build a circular business model and concrete implementation actions.

At the company level, the following tools for the application of the circular economy are identified: raw material / production analysis; life cycle assessment, implementing innovation in ecoprocesses and industrial symbiosis.

The sectors that are best placed to succeed in the application of the principles of a circular economy are automotive, machinery and equipment, incl. medical equipment, power generation and electrical equipment, computer production, etc. (5)

There is no program or project in the European Union by now that is specifically geared to the circular economy, but there are different studies that highlight the need to work in this direction. In general, the circular economy is a serious challenge for different sectors of the European economy. Moreover, there is no universal indicator for the so-called "Circulation" of the processes. According to the European Commission data, 8 billion tons of materials and raw materials are used annually in the European Union economy, of which only 0.6 billion tonnes are received from recycling.

2.2 billion tonnes of waste are generated in the EU production process, of which only 0.6 billion tonnes are recovered or re-used. The remaining 1.6 billion tonnes remain waste. That is why the monitoring of the principles of a circular economy in the European Union is of key importance. In 2018 it was implemented in four directions: production and consumption; waste management; use of recycled products; competitiveness and innovation. (3). The specific benchmarks for the four strands are summarized in Table 1.

Table 1. Main indicators for monitoring and opportunities for circular economy in Bulgaria

\begin{tabular}{|l|l|}
\hline Indicators for monitoring & Opportunity for circular economy \\
\hline $\begin{array}{l}\text { Share of key raw materials for which Bulgaria is } \\
\text { not dependent on the foreign market }\end{array}$ & $\begin{array}{l}\text { Serious opportunities for using bio-waste from } \\
\text { agriculture }\end{array}$ \\
\hline Percentage of generated waste (household) & $\begin{array}{l}\text { Increase municipal waste by 8\% over the past 5 } \\
\text { years. Need for measures. }\end{array}$ \\
\hline Share of recycled materials for reuse & An increase of 62 to 66\% over the past 10 years. \\
\hline $\begin{array}{l}\text { Percentage of recycled specific waste (plastic, } \\
\text { etc.) }\end{array}$ & $40 \%$ recycling, which is a low share. \\
\hline Import and export of recycled materials & $\begin{array}{l}\text { Export of raw material for recycling (mainly } \\
\text { plastic waste) }\end{array}$ \\
\hline $\begin{array}{l}\text { Number of patents for waste management and } \\
\text { recycling }\end{array}$ & $1 \%$ share of patents in the EU \\
\hline
\end{tabular}

The figures in Table $\mathbf{1}$ show a certain lag behind this criteria related to the utilization of the region's capacities (Bulgaria).
Local and regional authorities have an important role to play in initiating and accelerating the transition to a circular economy, either by introducing a clear regulatory framework or 
directly by supporting the affected parties concerned, including:

- As already mentioned, local authorities may introduce "green" criteria into their public procurement as consumers of goods and services. In practice, this means assessing the lifetime costs of the product, imposing energy efficiency criteria for sustainability in the maintenance, recycling possibilities and / or use of recyclable resources;

- Local and regional authorities can integrate the policy of promoting the circular economy with relevant strategic documents, including the planned measures and forms of support. This sends a clear signal to stakeholders and encourages them to plan for the long term. The Circular Economy should find its way into regional operational programs co-financed by the EU, local programming documents, thematic and sectoral strategies;

- Local and regional authorities can offer support by providing targeted funding, access to knowledge and information, as well as opportunities for networking and international exchanges. The financial support for the circular economy may take various forms including grants, loans, tax relief, investment guarantees directly provided by the public authorities or through intermediaries such as business associations or development agencies. By sharing experience, organizing events or creating information platforms, cities and regions can initiate and help the other parties - businesses, NGOs, academics and utility providers.

According to the EU Eco-innovation Observatory, the regional indicators for a circular economy are limited to (6):

1. Sustainable resource management - involves the study of three main indicators: (a) material footprint measured by internal consumption of materials per tonne per capita. The material footprint defines "the search for material resources (biomass, non-metallic minerals, rubies, etc.) for consumption and investment by households, governments and business environments" 6) resource productivity measuring " the total amount of materials directly used in the economy and / or for internal consumption compared to the level of GDP'; (c) municipal solid waste generated and recycled, measured in $\mathrm{kg}$ per capita.

2. Social behavior - includes the study of the following four indicators: a) number of citizens who have opted for alternatives for purchasing new products, incl. from recycled materials; b) media coverage with topics for the circular economy, incl. number of publications; (c) the turnover of personal goods subject to repairs (eg
TURLAKOVA T. personal computers); (d) the number of firms involved in the repair of goods for personal use.

3. Business operations - involves researching the following six indicators: a) difficulties in introducing the principles of circular economy into the business of the companies; b) sources to finance activities related to the circular economy; (c) accessibility of information in favor of funding with sources for activities related to the circular economy; (d) a share of firms that facilitate the recycling of products after their use; (e) a share of firms implementing measures to increase the life cycle of products through ecoinnovation; f) share of companies that recycle waste and / or materials for their own needs, as well as sell to other companies.

The illustrated indicators are another proof that the economy and business need new concepts, strategies, models and indicators to take into account the effects on the environment resulting from the human activity.

\section{REFERENCES}

1. Desrochers, P. Cities and Industrial Symbiosis: Some Historical Perspectives and Policy Implications. // Journal of Industrial Ecology, Vo1. 5, N24, 2001, pp. 9-44.

2. Ellen MacArthur Foundation, Towards the Circular Economy 1: Economic and business rationale for an accelerated transition; January 2012.

3. European Commission. Communication from the Commission to the European Parliament, the Council, the European Economic and Social Council and the Committee of Regions on a monitoring framework for the circular economy, COM (2018) 29 final: 16.01.2018, pp. 1-10.

4. European Parliament Science Advisory Council, $2015 \quad$ (http://www.easac.eu/ fileadmin/PDF_s/reports_statements/EASAC _Circular Economy_Web_revi sed.pdf).

5. European Parliamentary Research Service, European Parliament. Understanding Waste Streams: Treatment of Specific Waste, 2015 (http ://www . europ ar1. europa. eu/RegD ata/etude sBR1E/2 015/5 6439 8/EPR S_ BRI(2015)564398-EN.pdf).

6. Galuchi,T.and other, Inovation models of circular economic, UE-Varna, V.,2018

7. Lacy, P., J. Rutqvist. Waste to Wealth: The Circular Economy Advantages. Accenture Strategy edition, 2015., p.50-61.

8. McArthur Foudation, 2015 (https: //www.ellenmacarthurfoundation.org/ casestudies).

9. Pearce, David W. R. Kerry Turner Economics of Natural Resources and the Environment, Johns Hopkins University Press,UK, 1990. 